\section{Inhibition of Human Serum Cholinesterase by some 4-Hydroxy-coumarin Derivatives}

OF the esters of di(4-hydroxycoumarinyl-3)-acetic acid ('pelentanic acid' according to Fučík, Procházka and Cechová ${ }^{1}$ ), one, the ethyl ester ('Pelentan'), has been widely used as an anticoagulant. It has been reported ${ }^{2}$ that 'Pelentan' is less toxic than dicoumarol, acts with less delay and is more quickly eliminated. During a pharmacological study of 'Pelentan', it was found that its solutions inhibit human serum cholinesterase. In continuation of these observations, a comparison has been made of the inhibition of serum cholinesterase by some esters of pelentanic acid and by dicoumarol.

As all these compounds are poorly soluble in water, they were first dissolved with three times their equivalent of sodium hydroxide, and the solutions were then adjusted to $p \mathrm{H} 7 \cdot 4$ with hydrochloric acid. Cholinesterase activity was estimated by Ammon's ${ }^{3}$ manometric method. Each determination was made with $0.05 \mathrm{ml}$. of serum, which had been kept in the ice-box not longer than three days. Serum and inhibitor were placed in the side-bulb and the volume made up to $0.5 \mathrm{ml}$. with Ringer $30^{4}$. Acetylcholine hydrochlorido was dissolved in Ringer 30 ( $1.5 \mathrm{ml}$.) and placed in the main compartment. The results did not differ when, alternatively, inhibitor was placed in the main compartment.

Cholinesterase activity was expressed in terms of Augustinsson's ${ }^{4} b_{30}$, which represents the volume of carbon dioxide in $u 1$. evolved by the enzyme in 0.05 $\mathrm{ml}$. of serum during the 10th to 40th minute after tipping. Eight to ten tests were made with each compound and with each concentration of 'Pelontan'. Mean values are given in the accompanying table. The variations of the results were small.

The graph shows that the relationship between the negative logarithm of concentration of 'Pelentan' and the per cent inhibition of cholinesterase is linear.

As may be seen from the table, dicoumarol has about half the inhibitory effect of 'Pelentan'. Pelentanic arid, which is derived from dicoumarol by the replacement of one hydrogen of the methylene bridge by carboxyl and has no anticoagulant properties $^{5}$, does not inhibit appreciably. Esters of the acid had inhibitory activity increasing with the length of the esterifying radical over the range $C_{1}$ to $C$



Inhibition of serum cholinesterase by 'Pclentan' $\left(R=\mathrm{C}_{\mathbf{3}} \mathrm{H}_{5}\right)$ of various concentrations; acetylcholine hydrochloride as substrate in molar concentration of $2 \cdot 064 \times 10^{-2}$
INHIBITION OF SEROM CHOLINESTERASE BX DFRIVATTVES OF DICOONAROI Final inhibitor concentration $2.24 \times 10^{-4} \mathrm{M}$; acetylcholine hydrochloride $2.064 \times 10^{-2} \mathrm{M}$

\begin{tabular}{|c|c|c|}
\hline Compound & Mol. weight & $\%$ Inhibition \\
\hline 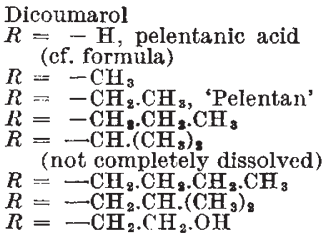 & $\begin{array}{l}338 \\
380 \\
394 \\
408 \\
422 \\
\\
422 \\
436 \\
436 \\
424\end{array}$ & $\begin{array}{r}27 \cdot 4 \\
1 \cdot 9 \\
7 \cdot 8 \\
42 \cdot 7 \\
54 \cdot 7 \\
(53 \cdot 7) \\
54 \cdot 4 \\
58 \cdot 7 \\
12 \cdot 2\end{array}$ \\
\hline
\end{tabular}

Straight- and branched-chain compounds of the same molecular weight were about equally effective. The glycol ester, which differs from 'Pelentan' by one- $\mathrm{OH}$ group in the esterifying radical, has a much lower anti-cholinesterase activity ; it is also a weaker anticoagulant ${ }^{6}$. 'Pelentan' also inhibits the cholinesterase of rat serum.

Until in vivo experiments have been evaluated, no claim can be made of the physiological significance of the inhibition of serum cholinesterase by these anticoagulant drugs.

$\mathrm{We}$ are indebted to Dr. K. Fučík and Mr. Z. Procházka of the United Pharmaceutical Works, Prague, for the supply of all the inhibitors tested.
V. Grossmann
I. M. Hals
B. Kasaixck Y

Department of Pharmacology, Charles University, Albertov 4, Prague. Aug. 15.

1 Fứ́k, K. Procházka, Z, and Cechovó, Y. Chem listy, 43, 49 (1949). 'Petrácek, E., Cas. lék. ces., 83, 1204 (1944). Reiniš, Z., and Kubik, M., Schweiz. med. Wchschr., 78, 785 (1948). v. Kaulla, K. N., and Pulver, R., Schweiz. med. Wechsehr., 78, 806 (1948), Pulver, Gianella, C. V , and v. Kaulla, K. N., Experientia, 5, 125 (1949). ${ }^{s}$ Ammon, R., Pflügers Arch. ges. Physiol., 233, 486 (1933).

- Augustinsson, K.-B., Acta Physiol. Scand., 15, Supp. 52, 38, 24 (1948).

${ }^{5}$ Lehmann, J., Lancet, i, 458 (1943).

- Francová, V. (personal communication).

\section{Demonstration of Incomplete Rh-Antibodies by Alpha-Globulin}

A METHOD of demonstrating incomplete $R h$-antibodies by suspending the reacting cells in a concentrated albumin solution has been described by Diamond ${ }^{1}$. The mechanism of the reaction is not clearly understood, and variations in the efficiency of different preparations of albumin suggest that the activating protein is not albumin, but some contaminating protein associated with it.

The fractionation of plasma by ether described by Kekwick, Mackay and Record ${ }^{2}$, and afterwards de. veloped for the preparation of gamma-globulin by Kekwick and Mackay ${ }^{3}$, made available a protein solution consisting of 87 per cent albumin and 13 per cent globulins which, when concentrated to 10 per cent protein, was found to demonstrate incomplete antibodies. The globulins from a 5 per cent solution of this protein were precipitated with sodium sulphate (18 gm. $/ 100 \mathrm{ml} .{ }^{4}$ ). The precipitate was dissolved in 0.9 per cent sodium chloride solution to one-tenth of the original volume, and the sodium sulphate was removed by dialysis. The supernatant was concentrated and found to be inactive; but the precipitate was active at a third of the protein concentration of the original solution. 